IJ§ER

ISSN: 2149-5939
International Journal of Social Sciences and Education Research

Online, https://dergipark.org.tr/tr/pub/ijsser

Volume: 6(3), 2020

Research Article

\title{
A good scare is worth more than good advice: Educational regulations in Italy and Turkey after CoVid-19
}

\author{
Ceyda Şensin ${ }^{1}$ and Émiliane Rubat du Mérac ${ }^{2}$
}

Received date: 27 / 07 / 2020

Accepted date: 20 / 09 / 2020

\begin{abstract}
Interrupting educational services due to the CoVid-19 outbreak can have serious and long-term consequences. This paper addresses the comparisons of the Educational Regulations in Italy and Turkey after CoVid-19 on inservice teacher training. The purpose of this cross-cultural research is to examine the content and the quality of training that is provided to Turkish and Italian teachers in service. In this study, the document scanning method was used. In-service teacher training activities within the two education structures had been investigated through document scanning. In general, despite the differences in the general framework of teacher training in these two countries, they both pay more attention to teacher training right after the CoVid-19 outbreak. Based on the findings of the study, suggestions are made about in-service training activities in Turkey and Italy.
\end{abstract}

Keywords: CoVid-19, Educational policy actions, In-service teacher training, Italy, Turkey.

\section{Introduction}

Interrupting educational services due to the global closure of schools with the nature of countermeasures against the COVID-19 outbreak can have serious and long-term consequences, such as increased inequality and health problems in society, and decreased social cohesion. Governments are obliged to work simultaneously to support and protect the right to education, health, and safety of each child, as stated in the Convention on the Rights of the Child. In fact, the General Secretary of the United Nations called on governments to prioritize education for all children, including disadvantaged children. At the online meeting organized by UNESCO on April 29, 2020, it was determined that according to the measures offered by education ministers, even though most governments have not set precise dates to reopen their schools, they are planning a phased approach. At the same meeting, the "Framework for Reopening Schools" (2020), which was published jointly by UNESCO, UNICEF, the World Bank, and the World Food Program, was highlighted. It also aims to support the national preparations and guide the implementation process within the framework of which it is intended to guide the decisions of schools about why, when, and how to re-open. UNICEF Education Director Robert Jenkins and World Bank Global Education Director presented the framework and stated that the further away from school, the more difficult it is to return to school. Accordingly, the ministers who attended the online meeting shared their progressive approach towards the re-opening of the schools, while remaining loyal to the distance learning plan until all students returned to school completely.

${ }^{1}$ Dr., National Education Specialist, Ministry of National Education in General Directorate of Teacher Training and Development in Turkey. ORCID: 0000-0002-3036-0221 E-mail: ceyda.sensin@uniroma1.it

${ }^{2}$ Dr., Lecturer, Università degli Studi di Roma "La Sapienza" at Department of Social and Developmental Psychology and Educational Research in Italy. ORCID: 0000-0003-0575-7021 E-mail: emiliane.rubatdumerac@uniroma1.it 
Şensin, C., Rubat du Mérac, É. (2020). A good scare is worth more than good advice: Educational regulations in Italy and Turkey after CoVid-19. International Journal of Social Sciences and Education Research, 6(3), 429-442.

According to the "Framework for Reopening Schools", the necessity for schools to be opened has been explained as the basis of the impact of the school on the child's learning ability, eliminating the risk of being exposed to anxiety and stress, such as sexual abuse that may be caused by being away from school, child and forced marriage, violence, lost peer interaction and routines. Accordingly, the healthiest way to be followed in reopening schools is; opening safely by health intervention with all measures to protect students, school staff, teachers, and families.

Countries to make a serious decision such as opening schools; school principals and local administrators should quickly gather critical information about how to deal with the epidemic with quick surveys to be applied to teachers, students, and parents, and in the light of this information, consider how to support learning by considering the risk factors associated with opening schools and the benefits of classroom education compared to distance education.

Before schools reopen:

- It has been suggested that teachers and school administrators should be given support and education on distance education while schools are still closed. For this, peer groups can be created on mobile platforms, as well as providing telephone credit (credit/minute) for them to communicate with parents.

- In order to prevent teachers from wearing out and to support their professional development, it was suggested that teachers' salaries should be paid continuously and on time.

In the process of reopening schools:

- It has been suggested that administrative staff and teachers should be trained on physical distance application and school hygiene practices, and if necessary, the number of staff in schools should be increased.

- It has been suggested to support teachers in the mental health and psychosocial needs of students as well as compensating for the places that are lagging behind in education. The training to be given within this scope, especially in schools where the ratio of students at risk is high; It is suggested that teachers be organized in a way that aims to improve students' basic literacy and mathematical skills and to improve their ability to meet their socio-economic needs.

When schools reopen:

- It is recommended to seek help from experts to implement innovative methods such as peer counseling in professional development online and to make the process run faster. It is suggested that these training can be combined with formal pre-service and in-service teacher training.

- It has also been proposed to increase the funds allocated for the development and training of teachers.

\section{In-service teacher training}

The previous passage explains how it is recommended to pay attention to teacher training during the historical period of school closure due to the CoVid-19. In-service training is a term used to describe a range of activities and requirements, often under the title of professional development. In-service education with the definition of Perron (1991; quoted by EURYDICE, 1995) as various activities and practices they involve in expanding teachers' knowledge, developing

Copyright (C) by International Journal of Social Sciences and Education Research 
Şensin, C., Rubat du Mérac, É. (2020). A good scare is worth more than good advice: Educational regulations in Italy and Turkey after CoVid-19. International Journal of Social Sciences and Education Research, 6(3), 429-442.

their skills, and evaluating and developing their professional approaches explains the meaning of professional development.

One of the most important components of this training is the teacher. The key factors in inservice training are to positively affect the professional development of teachers and to contribute to the development of their knowledge by taking an active role (Saiti \& Saitis, 2006). A similar definition is made by Loucks-Horsley et. al. (2010) as teachers' professional development concept as opportunities to increase teachers' activities in the classroom and develop new knowledge, skills, and approaches.

The developments both in science and technology since the mid-20th century brought about changes in societies. While all these developments strengthen the role of the teaching profession in society, it also forces teachers to be changed, to constantly develop themselves. In the $21 \mathrm{st}$ century, the teacher, who was defined as the person who only conveyed the knowledge in the past years, evolved to the person who designed his own materials, methods, classroom activities, and all kinds of teaching-related situations. For this reason, many countries have invested in their teachers a priority, realizing that it is not possible to catch up with the knowledge level of the constantly developing world only through the education received before the service, and has also given importance to the professional development of teachers after the service. Especially after the CoVid-19 pandemic, it can be seen that one of the most common points of the regulations on education was to strengthen the teacher training services. At below, some of the regulations on education based on in-service teacher training made in some countries due to the pandemic.

The "Distance Learning" initiative in the United Arab Emirates was carried out in cooperation with the Ministry of Education and Hamdan Bin Mohammed Smart University (2020). According to this initiative, more than 42,000 online connections have been successfully given the 'Be an online teacher within 24 hours' course with this distance education. This course aims to provide participants with the necessary training on various levels of training staff about online training processes, including managing online classes, operating them online, and helping them gain the necessary experience. Provided in Arabic and English, this course is free and is designed to further develop the ability of academic professionals to provide quality distance learning by international best practices and is supported by "Madrasa", an Arabic and English e-learning platform. The collaboration was provided for the educators on the provision of the "Become an online teacher in 24 hours" course in five global languages (English, Russian, French, Spanish and Arabic), in cooperation with the university and UNESCO. After this completed online course, the second session titled 'Design an Online Course in 24 Hours' will start next.

In the time of the epidemic, the Government of Spain has made it a priority to eliminate deficiencies in the measures to be taken in the field of education, due to the disruption of the content, courses, subjects, and curriculum in all circumstances due to extraordinary conditions. After proposals such as making use of all areas of training centers, combining face-to-face activity with remote activity or adapting programs, the Ministry (2020a) Economic Affairs to design a regional cooperation program for teacher education, which will enable the digitalization of increased resources to strengthen digital resources and skills through platforms and devices and announced that they are working with the Ministry of Digital Transformation. It was also announced that intensive teacher training activities would be developed to provide technical equipment to training centers and to use online resources. The Minister of Education (2020b) stated that priority should 
Şensin, C., Rubat du Mérac, É. (2020). A good scare is worth more than good advice: Educational regulations in Italy and Turkey after CoVid-19. International Journal of Social Sciences and Education Research, 6(3), 429-442.

be given to improving teacher education and modernizing vocational education, accordingly, the National Institute of Educational Technologies and Teacher Training (Instituto Nacional de Tecnologías Educativas y de Formación del Profesorado -INTEF) website (https://intef.es/recursos-educativos/recursos-para-el-aprendizaje-en-linea/) has suggested its use to provide information to teachers, families, and students on different topics. Since there are no published regulations in the process of providing in-service training face-to-face, teachers are expected to improve their professional education using the materials on this website.

While the reopening process of schools in France was announced to be gradual, it was determined that the curriculum was changed and adapted to each level by considering the shortened academic year. To support teachers in this process, the Ministry provided them with a series of "objectifs pédagogiques prioritaires (priority educational objectives)" page and assessment exercises for each level of assessing students from kindergarten to grade 3 from primary school (Government of France 2020).

The Australian Government (2020) pursues a policy in which teachers and parents support collaborative work with states, regions, and non-government education authorities to support teachers, school leaders, and school communities to continue delivering high-quality education during the outbreak. In addition, the Australian Institute for Education and School LeadershipAITSL plays an important role in developing expertise in education and supporting a quality teaching and school leadership profession, making several resources open to teachers to support teachers and leaders. AITSL launched an Australian Teacher Response Campaign, which includes a material center for teachers and a Facebook group during the outbreak (https://www.aitsl.edu.au/secondary/comms/australianteacherresponse).

It is crystal clear that countries pay attention to teacher investment and in-service teachers are playing a key role to pass through this historical time. Therefore, in this paper, it was aimed to investigate the regulations on education based on in-service teacher training strategies after CoVid-19 outbreak. The following research questions are addressed for both countries:

- What is the general framework for in-service teacher training activities organized both in Italy and Turkey?

- What types of in-service teacher training activities are furnished both in Italy and Turkey after the CoVid-19 outbreak?

- What actions ought to be taken to provide better in-service schooling activities for teachers in Turkey and Italy?

\section{Methodology}

The research was carried out using a document analysis method. Document analysis takes place by examining the documents to reach the data for the research objectives (Çepni, 2010). In addition, related professional and legal documents had been investigated and examined. Regarding with the subject with the keywords such as in-service teacher training, "la formazione in servizio degli insegnanti" and "hizmet içi öğretmen eğitimi" were scanned in national and international searching indexes such as Google Scholar, INVALSI, Ulakbim, YÖK database, Science direct and, EBSCO. The reports of in-service teacher training that are published by European Education Data Net (EURYDICE), the Ministry of National Education (MEB), and Ministry of Education, University and Research (MIUR) had been scanned.

Copyright (C) by International Journal of Social Sciences and Education Research 
Şensin, C., Rubat du Mérac, É. (2020). A good scare is worth more than good advice: Educational regulations in Italy and Turkey after CoVid-19. International Journal of Social Sciences and Education Research, 6(3), 429-442.

\section{Results}

Among all European countries, Italy had the largest set of Covid-19 cases which has temporarily closed all schools and universities starting from March 4, 2020, in order to implement strict measures to prevent further spread of the new coronavirus (MIUR, 2020a). As Özer (2020) mentioned, due to the school closure starting from March 17, 2020, MoNE taken significant steps to strengthened to sustain distance education based on policy actions. This comparison study is limited to the key dimensions and presented in main categories accordingly; general frameworks for in-service teacher training and the in-service teacher training regulations after CoVid-19 in both of the target countries.

\subsection{In-service teacher training in Italy}

\subsubsection{General Frameworks for in-service teacher training in Italy}

The implementation of these training initiatives is entrusted by this General Directorate to the Regional School Offices to acquire the candidacies of state Educational Institutions or their networks, starting the selection procedures for the current school year. The general objective is to develop teachers to expertise on subjects with specific skills on the teacher training plan. These "expert" teachers will then be called to cascade dissemination (one or more teachers per institute) of the strengthened and/or acquired skills and to be promoters and tutors of the introduction and the curricula of their use. The in-service training plan must provide a common basis for competing on the planning and organization of interventions with the acquisition of advanced techniques and teaching methods that are at the same time rigorous, innovative, and engaging and includes practical tools essential to manage effective classrooms (MIUR, 2018).

In-service training of tenured teachers is compulsory, permanent and, structural. The methods of carrying out in-service training are decided by the board of teachers, on the basis of the threeyear plan of the training offer "PTOF", within which adequate space must be reserved for the Plan of training actions. The objective of the plan is to respond to the training needs of individual teachers to be included in the development and improvement framework of each school (Official Newspaper of the Italian Republic, 2015,).

In planning the training activities, compliance with the quality criteria must be ensured, in relation to the relevance of the cultural contents, to the diversification of the methodologies to focus on training workshops, on research-action, on networking and, on the production of teaching resources.

A few points of attention are summarized:

- The in-service teacher training would express the needs of the schools find the right consideration in the plans built at a territorial level;

- The training would encourage the use of didactic research and field training activities focused on observation, reflection, comparison on didactic practices and their results, avoiding abstract and academic treatments;

- The training would enhance schools and innovative experiences, promoting forms of twinning, exchange of teachers, visiting;

- The training would involve university structures, professional associations, bodies and, qualified/accredited subjects in a more incisive way, to enrich the cultural, scientific and, methodological quality of the training activities. 
Şensin, C., Rubat du Mérac, É. (2020). A good scare is worth more than good advice: Educational regulations in Italy and Turkey after CoVid-19. International Journal of Social Sciences and Education Research, 6(3), 429-442.

\subsubsection{Regulations made in in-service teacher training in Italy after CoVid-19}

Operational indications for carrying out in-service training activities for teachers, as well as training activities for newly hired teachers, in light of the urgent measures on the containment and management of the epidemiological emergency from COVID-19 taken. It was noted on the protocol with number 278 on the March 6, by MIUR (2020c)that all the activities should be carried out by smart working until the emergency ceases and in any case until different communication from the competent authorities which includes the training activities aimed at newly recruited teachers in 2019-2020 school year, the activities to teachers that engaged in support activities, inservice teacher training, the training to newly-hired school managers in 2019-2020 and all the training in general meaning.

The training and test course for newly recruited teachers is characterized by activities that are generally carried out in the presence. Reference is made in particular to training workshops and peer to peer activities. In addition, this is the third school year in which the experimental activity of visiting innovative schools is also planned, addressed to 3,000 newly recruited teachers throughout the national territory. Also, for these training activities, it is, therefore, necessary to identify online distance training methods.

The training workshops, characteristic of the year of training and testing, are generally divided into four 3-hour meetings each on the topics envisaged by the Ministerial Decree. Without prejudice to the total duration of 12 hours of total use for the laboratories, it is advisable to propose for each newly hired teacher the frequency of only two laboratories in remote mode, in order to dedicate adequate time to both activities in sync (video lessons, interaction in the virtual classroom, etc.) and at the moments of preparation, personal study, and reworking, with final feedback provided by the trainer. The role of the trainer must be based on facilitating relations between newly recruited teachers, also in this new training context. The laboratories are managed remotely, through synchronous and asynchronous instruments, some of which are reported through the special section of the ministry dedicated to online teaching (https://www.istruzione.it/coronavirus/index.html), and are possibly also carried out with the support and involvement of the educational institution of the newly recruited through the digital animator and/or the territorial training teams to support educational innovations. On the INDIRE website, in the new hiring section of the school year 2019-2020, some examples of articulation and useful methodologies for the creation of online laboratories are available. Conducting the online workshops presupposes a familiarity with the trainers with the online tools. The pole school for training will take care to ensure a technical and functional infrastructure that makes synchronous (video conferencing, webinar, chat, virtual classrooms, etc.) and asynchronous (e.g. repository for material sharing) and specialist online tutoring support environments (e.g. animator and digital team and / or territorial team for innovation).

Peer to peer is one of the fundamental activities of the year of training and testing. In the 12 hours provided for this activity, the most significant part of the relationship between the newly hired teacher and his welcoming tutor is expressed. This activity involves the design, the structured and mutual observation of the didactic action in the respective classes, the shared reworking of what has been observed. Having to and wanting to experiment with this activity during the time of suspension of teaching in the presence, it is suggested to carry out the planning observation in relation to the distance teaching opportunities that each teacher is putting in place in each other's

Copyright (C) by International Journal of Social Sciences and Education Research ISSN: 2149-5939 
Şensin, C., Rubat du Mérac, É. (2020). A good scare is worth more than good advice: Educational regulations in Italy and Turkey after CoVid-19. International Journal of Social Sciences and Education Research, 6(3), 429-442.

classes. The observation grids for the didactic activity available in the Toolkit of the online environment neoassunti.indire.it remains useful for the peer to peer activity, taking care to adequately transpose the activities carried out online with particular regard to the centrality of the educational relationship, even in remote situations, mediated by technologies.

The visiting activity in innovative schools, among the many activities in attendance, is certainly the one that can undergo the greatest variation compared to what has already been planned. The organized meeting of the study visit cannot be easily borrowed in its "remote" equivalent. However, if in the spirit of the experimental initiative there is the intention of "going to meet educational institutions that offer innovative ideas and examples of good practice" it is important to take the opportunity to make contact (in a virtual way and through online meetings ) with the good practices shared by the schools also to cope with the moment of emergency, so as to spread innovative methods and operational tools to facilitate the creation of permanent collaboration networks between teachers of different educational institutions.

Pending the adoption of the Ministerial Decree and that the relative training resources are assigned, the training Polo schools which have the task of carrying out support and consultancy actions with local networks for the promotion of research, experimentation, and development of methodologies and use of didactic tools for inclusion, with part of the resources already available, will take care of planning, based on the needs of the local educational institutions, training courses aimed at enhancing the skills of teachers on methodologies and techniques for distance learning, also referring to the contents published in the dedicated section of the website of the Ministry of Education (https://www.istruzione.it/coronavirus/index.html) (MIUR, 2020b).

The National Institute of Documentation, Innovation, and Educational Research [INDIRE] in Italy (2020a) launched a solidarity initiative between schools to overcome the COVID-19 emergency with solutions for distance learning with innovative methodologies and tools. A solidarity that is realized thanks to the support of the networks of schools of the "Avanguardie educative", "Piccole Scuole" and the European community of "eTwinning" that are ready to collaborate with the teachers and school managers of the educational institutions based on requests.

Again, INDIRE (2020b) offered teachers a new section entirely dedicated to tutorials for distance learning. It is collection videos that guide the users step by step in order to use some of the main free tools to record video lessons, achieving them (i.e. Google Drive, One Drive), sharing online teaching resources, and virtual classroom management. The selected tools are free and ready to use (i.e. YouTube, PowerPoint, Screencast-O-Matic, Skype, Hangouts, Open Broadcast Software, Google Suite for Education, Microsoft Office 365 for Education, Google Classroom, Microsoft Teams, and WeSchool). The video tutorials are marked by color: green for those suitable for those who start from scratch, yellow for slightly more complex solutions, and finally red to indicate a further, progressive level of complexity/flexibility.

\subsection{In-service teacher training in Turkey}

\subsubsection{General Frameworks for in-service teacher training in Turkey}

The Ministry of National Education considers the needs in in-service training; regarding the developments in science and technology, executive reports, audit reports, staff requests, research results, board recommendations, surveys, relevant legislation, needs of units or institutions, development plans, action plans, and other top documents. In-service training activities are planned 
Şensin, C., Rubat du Mérac, É. (2020). A good scare is worth more than good advice: Educational regulations in Italy and Turkey after CoVid-19. International Journal of Social Sciences and Education Research, 6(3), 429-442.

and carried out by the General Directorate of Teacher Training and Development at the central level, and by the governorships at the local level. The in-service teacher training activities are provided to teachers and in professional and personal development; while the training activities are provided in areas such as candidacy, adaptation, renewal, development, and preparation for senior positions, changing fields, pedagogical formation, foreign language, computer, special education. Professional and personal development training is given in areas such as candidacy, adaptation, information renewal, development, and preparation for senior positions, changing fields, pedagogical formation, foreign language, computer, special education.

In-service training activities are planned and carried out by the Department of In-Service Training in the Ministry of National Education. Addressing the problems of centrally driven inservice training activities, the Department of In-Service Training gave local National Education Directorates authority and responsibility to plan and conduct in-service training according to their own needs. Since 1994, National Education Directorates in all provinces of Turkey have prepared their own annual in-service training plans and after these have been approved by the provinces' governors, they can conduct activities using their resources.

The general concept of in-service training at both the national and local level appears to involve determining an expert or experts for the activities and making the training. No matter what the course's subject is, the organizing authority generally invites an academician from a university or an experienced teacher and asks them to speak for the training activity. Collaborative and communicative activities in which the teachers share their knowledge and experiences are not generally used. The experts, academicians, and trainers who take part in the training cannot usually use information and communication technologies and interactive multimedia tools in the training activities because of the lack of facilities. It is usually used as a computer and a projection machine to do the presentation.

\subsubsection{Regulations Made in In-Service Teacher Training in Turkey after CoVid-19}

The review article by Özer (2020) explains the general educational policy actions by MoNE to maintain educational services once the CoVid-19 breakout. The Ministry of National Education is in the process of closure of schools in Turkey, Education Information Network (EBA) has strengthened the infrastructure of the educational portal is digital. Therefore, it has resulted in the same article that MoNE has rapidly established an in-depth distance education environment that supports students academically, improves the psychosocial support system, and provides the necessary materials and tools.

The 2023 Education Vision, which has been created as a road map has been built on our cultural codes by prioritizing making the living conditions of our recent times meaningful for the present and future of our children. Below, the objectives related to our General Directorate of Teacher Training and Development (ÖYGM) are listed as selected, and the arrangements and activities carried out by the general directorate during the CoVid-19 outbreak process (MoNE, 2020a). It was paid attention the teachers' professional development within national and internationally accredited distance education programs prepared in the field of digital entrepreneurship, computing thinking skills, project consultancy, English language education, museum and disaster education, and information from artificial intelligence to digital security were opened to approximately 500.000 teachers by the General Directorate of Teacher Training and Development in the

Copyright (C) by International Journal of Social Sciences and Education Research ISSN: 2149-5939 
Şensin, C., Rubat du Mérac, É. (2020). A good scare is worth more than good advice: Educational regulations in Italy and Turkey after CoVid-19. International Journal of Social Sciences and Education Research, 6(3), 429-442.

Ministry of National Education at the following webpage: http://ogretmen.meb.gov.tr/meslekigelisim-programi.html.

To support teachers and strengthen their personal and professional needs; within the support by universities, non-governmental organizations, and academics, the aforementioned online training program set up and accredited by the UNESCO National Commission. Before the pandemic process, it was accelerated the online training that has established and structured professional development programs in accordance with the distance education system (MoNE, 2020b).

Professional development programs to be counted as in-service teacher training that is shared online are grouped as follows:

\begin{tabular}{|c|c|}
\hline \multirow[t]{3}{*}{ Turkish Language } & Efficient Use of Turkish Language and Elocution Education \\
\hline & $\begin{array}{l}\text { Turkish Education Professional Development Program for Turkish Children in } \\
\text { Our Cultural Geography }\end{array}$ \\
\hline & $\begin{array}{l}\text { Teaching Turkish as a Second Language in the Context of Inclusive Education } \\
\text { Professional Development Program }\end{array}$ \\
\hline \multirow[t]{4}{*}{ Foreign Languages } & Professional Development Program of German Language Teachers \\
\hline & Professional Development Program of Arabic Language Teachers \\
\hline & Professional Development Program of French Language Teachers \\
\hline & Professional Development Program of English Language Teachers \\
\hline \multirow[t]{23}{*}{ Self-Development } & Introduction to Computer Networks Training (CCNA 1) \\
\hline & Python Training \\
\hline & Introduction to Cyber Security Training \\
\hline & Internet of Things (IoT) \\
\hline & Java Education (Basic Level) \\
\hline & Fundamentals of Digital Entrepreneurship \\
\hline & Teaching Computational Thinking Skills by Interdisciplinary Approach \\
\hline & Mobile Application Development with Flutter \\
\hline & Mobile Application Development with Kotlin \\
\hline & Computer-Aided Design (AUTODESK FUSION 360) \\
\hline & Project Consultancy Seminar \\
\hline & School-Based Disaster Education \\
\hline & Trekking (Summer / Winter) Leadership Professional Development Program \\
\hline & $\begin{array}{l}\text { Design Oriented Thinking Professional Development Program for Innovation in } \\
\text { Education }\end{array}$ \\
\hline & $\begin{array}{l}\text { Village Teachers and Unified Classroom Teachers Orientation and Professional } \\
\text { Development Program }\end{array}$ \\
\hline & School Family Cooperation Professional Development Program \\
\hline & $\begin{array}{l}\text { Professional Development Program of School Administrators in the Context of } \\
\text { Inclusive Education }\end{array}$ \\
\hline & Orienteering Education Professional Development Program \\
\hline & Professional Development Program for Autism Spectrum Disorder \\
\hline & $\begin{array}{l}\text { Development of Guidance Skills of Preschool and Guidance Teachers Profes- } \\
\text { sional Development Program }\end{array}$ \\
\hline & Software Development Specialist Professional Development Program \\
\hline & Intelligence Games Education Professional Development Program \\
\hline & $\begin{array}{l}\text { Professional Development Program for Teaching Computational Thinking Skills } \\
\text { by Interdisciplinary Approach }\end{array}$ \\
\hline
\end{tabular}

Copyright $(\mathcal{C}$ by International Journal of Social Sciences and Education Research

ISSN: 2149-5939 
Şensin, C., Rubat du Mérac, É. (2020). A good scare is worth more than good advice: Educational regulations in Italy and Turkey after CoVid-19. International Journal of Social Sciences and Education Research, 6(3), 429-442.

\begin{tabular}{|l|l|}
\hline \multirow{4}{*}{ Culture } & Mind and Intelligence Games Education Professional Development Program \\
\cline { 2 - 2 } & Drama Professional Development Program in Education \\
\cline { 2 - 2 } & Folk Dance Professional Development Program \\
\cline { 2 - 2 } & Anatolian Tales and Fairy Tale Narration Professional Development Program \\
\cline { 2 - 2 } & Museum Education Professional Development Program \\
\cline { 2 - 2 } & A Teacher A Thousand Rhythm \\
\hline
\end{tabular}

According to Can (2020), the period of CoVid-19 pandemic increased the demand for open and distance education; moreover, he strongly suggests that the distance education system should be strengthened in terms of infrastructure, access, security, content, design, implementation, quality, legislation and pedagogically in Turkey. Kırmızıgül (2020) highlights the result of the changes in the digital world and learning environments before and after the Covid-19 outbreak, inevitable changes have occurred in the education process and practices and given that reason, many changes have affected students, parents, education administrators and teachers. During the time of CoVid19 pandemic and digitalization in the education process; teachers, like students and parents, tried to keep up with digitized education in Turkey as the rest of the world. She claims that significant developments have been experienced in the knowledge and experience of teachers in technological and pedagogical fields especially when the live classes and live lessons were implemented by the Ministry of National Education (2020a; 2020b; 2020c) for teachers and students through Education Information Network [http://www.eba.gov.tr/] which has also been used for the teachers' professional development in CoVid-19 pandemic period. The in-service development program of teachers is also adapted to distance education where one can find online activities, egroups, and e-books based on professional development. The online groups let teachers grow a network based on their interests i.e. world of education in the 21 st world, educational technologies, classroom management and counseling, assessment and evaluation, and teaching techniques and methods (MoNE, 2020c).

The trending teacher training in the field of Information Technologies are organized synchronously and asynchronously in order to develop the knowledge, skills, and expertise of teachers are as follows:

- In cooperation with Cisco; introduction to computer networks (CCNA 1), Python, cyber security, Internet of Things (IoT)

- In cooperation with Oracle; database and java (both for basic level)

- In cooperation with Google; Fundamentals of digital entrepreneurship,

- Software development with Flutter and Kotlin

- Teaching computational thinking skills with an interdisciplinary approach

- In cooperation with Autodesk; Computer Aided Design

- In collaboration with Apple; "Anyone Can Code"

Apart from these training, where it was aimed to increase teachers' software developing skills in many branches such as artificial intelligence, embedded systems, robotics, and big data; the other trending online training activities are the Project Consultancy Seminar prepared in collaboration with the Scientific and Technological Research Council of Turkey [TÜBITAK] in order to improve the knowledge and skills of teachers who prepare students for TÜBITAK projects and carry out project consultancy; the Museum Education Certificate Program prepared in collaboration with Ankara University Museum Education Department, where it was planned to enable

Copyright (C) by International Journal of Social Sciences and Education Research

ISSN: 2149-5939 
Şensin, C., Rubat du Mérac, É. (2020). A good scare is worth more than good advice: Educational regulations in Italy and Turkey after CoVid-19. International Journal of Social Sciences and Education Research, 6(3), 429-442.

teachers to transform museums into out-of-school learning environments and use them by making interdisciplinary associations and finally the School-Based Disaster Education prepared in cooperation with AFAD-JICA aims to increase the awareness, knowledge, and skills of teachers about natural disasters (MoNE, 2020d).

\section{Conclusion}

The CoVid-19 disease is an unexpected challenge in all the countries' national education system. Knowing that teachers are the core of the education system, yet the forced adjustments putting all the activities in an online portal could be seen as a challenge where it can be read as an opportunity also to provide in-service teacher training to improve old-school teachers. Given that reason, this paper is in quality to enlighten the Similarities and Differences between Italy and Turkey after CoVid-19 on In-Service Teacher Training Regulations in order to learn from each other and get improve. When the regulations of Italy and Turkey were examined, some similarities came out. Lack of professional staff for planning and accomplishing in-service teacher training activities both in Turkey (Bayrakç1, 2009) and Italy (Causarano, 2004) seems to be one of the main problems for teachers' professional development.

Given the circumstances challenging education systems in the worldwide meaning; it can be useful to highlight the similarities and learn from each other in order to avoid mistakes that can cause bigger problems in the near future. In these two countries, it can be seen that, like in other countries, the biggest common point was to strengthen the teachers' information technology skills. Telli and Altun (2020) recommend that investing in online and distance education must be the strategy to follow. According to them, teachers are expected to be in need of specific training be for the preparation of asynchronous education. In order to prepare content suitable for students who will encounter asynchronous education content and online education system; education technologies, training scenarios, preparing e-learning scenarios, and creating these prepared e-learning scenarios with basic Microsoft Office tools or rich multimedia contents such as Articulate, Captivate, iSpring. As the increase in online video conferencing tools such as Google Meet, Google Hangout, Zoom, Blackboard, Cisco and Webex are also can be taken into consideration.

Given the fact that that the most common problem faced by teachers was the problem of inviting students to the online course or adding them to the class. In order to prevent various complications that can be experienced, the usage guides of the most used live video applications can be prepared and presented to the teachers (Telli and Altun, 2020).

There were not found any document depending on the disability, instructors or teachers with disabilities in order to support them, therefore, it is suggested that it can be useful to use the educational platform or live video class application on the computer interface and special access and usage guides should be prepared (Telli and Altun, 2020).

Both in Italy and Turkey, the current distance education system is supported by many national and international networks and communities. It is highly recommended to strengthen international networks and learn from each other and then nationalize the possible strategies.

On the other hand, based on the general frameworks, both of the national in-service teacher training activities are organized as one-way learning. As known as communication among teachers is a key for fostering teachers' professional development; teachers can learn better from each other than from a content expert or an education specialist (Park et al., 2007). In light of that, it 
Şensin, C., Rubat du Mérac, É. (2020). A good scare is worth more than good advice: Educational regulations in Italy and Turkey after CoVid-19. International Journal of Social Sciences and Education Research, 6(3), 429-442.

can be suggested that the in-service teacher training activities can be organized in order to learn from each other even through online portals. Based not only on the obligatory training activities but also on the interests in order to develop the skills, official e-groups can be launched on official webpages provided by the ministries of national education. Within that, it can be easier to provide feedback due to the importance of feedback stated by Duke (1986; cited in Bayrakçı, 2009) that when a training activity is followed by provision for feedback, it will result in the best involvement by the teacher. It must be also highlighted that according to Andrade (2015), specific strategies for educators should be implemented that aim to improve student autonomy in teacher education for online teaching. In this approach; if the contents of dialogue, autonomy, self-regulated learning, self-reflection, collaborative control, peer, and teacher cooperation are solidly created and gained with an effective infrastructure, then teachers can guide a qualified online teaching and learning experience.

\section{References}

Andrade, M. S. (2015). Teaching online: A theory-based approach to student success. Journal of Education and Training Studies, 3(5), 1-9.

Bayrakc1, M. (2009). In-service teacher training in Japan and Turkey: A comparative analysis of institutions and practices. Australian Journal of Teacher Education, 34(1), 2.

Can, E. (2020). Coronavirüs (Covid-19) pandemisi ve pedagojik yansımaları: Türkiye'de açık ve uzaktan eğitim uygulamaları. AUAd, 6(2), 11-53.

Causarano, P. (2004). La formazione e l'aggiornamento degli insegnanti secondari nell'Italia repubblicana: una prima ricognizione. La storia contemporanea tra scuola e universita. Soveria Mannelli: Rubettino, 177-199.

Çepni, S. (2010). Araştırma ve Proje Çalışmalarına Girişs, 5. Baskı. Trabzon.

Eurydice. (1995). In-service training of teachers in the European Union and the EFTA/EEA Countries, ed. Eurydice, Brussels.

Government of Australia, the Department of Education, Skills and Employment. (2020). Resources for teachers and school leaders. https://dese-interim.govcms.gov.au/resources-teachers-and-school-leaders.

Government of France. Ministry of Education. (2020). Réouverture des écoles et des établissements scolaires: Conditions de poursuite des apprentissages. https://www.education.gouv.fr/bo/20/Hebdo19/MENE2011220C.htm.

Government of Italy, Ministry of Education [MIUR]. (2020a). Coronavirus, Azzolina: attività didattiche sospese fino al 15 marzo. https://www.miur.gov.it/web/guest///coronavirus-azzolina-attivita-didattichesospese-fino-al-15-marzo.

Government of Italy, Ministry of Education. [MIUR]. (2020b). Dipartimento per il sistema educativo di istruzione e di formazione. Nota MI-DGPER prot. 7304. http://www.indire.it/wp-content/uploads/2020/03/nota_DGPER_27_03_2020.pdf.

Government of Italy, Ministry of Education. [MIUR]. (2020c). Prot. Note 278 of 6 March 2020 (Version 1.0). https://www.miur.gov.it/web/guest/viewasset//asset_publisher/JSNbzntsYmTr/document/id/ 2586222?_com_liferay_asset_publisher_web_portlet_AssetPublisherPortlet_INSTANCE_JSNbznts YmTr_redirect $=$ https://www.miur.gov.it/web/guest/viewasset $\% 3 \mathrm{Fp} \_\mathrm{p} \_$id\%3Dcom_liferay_asset_ publisher_web_portlet_AssetPublisherPortlet_INSTANCE_JSNbzntsYmTr\%26p_p_lifecycle\%3D0\% 
Şensin, C., Rubat du Mérac, É. (2020). A good scare is worth more than good advice: Educational regulations in Italy and Turkey after CoVid-19. International Journal of Social Sciences and Education Research, 6(3), 429-442.

26p_p_state\%3Dnormal\%26p_p_mode\%3Dview\%26_com_liferay_asset_publisher_web_portlet_AssetPublisherPortlet_INSTANCE_JSNbzntsYmTr_cur\%3D0\% $\%$ _6 _liferay_asset_publisher_web_portlet_AssetPublisherPortlet_INSTANCE_JSNbzntsYmTr_assetEntryId\%3D2586222.

Government of Italy, Ministry of Education. [MIUR]. (2018). Orientamenti pedagogici sui LEAD: Ministero dell'Istruzione, dell'Università e della Ricerca Dipartimento per il sistema educativo di istruzione e di formazione Direzione generale per il personale scolastico. https://www.miur.gov.it/documents/20182/718927/Nota+DG+personale+scolastico+protocollo+50912+del+19+novembre+2018.pdf/830eb60d-ac25-4cf3-b174-ab350b2a8b10?version=1.1\&t=1542737185301.

Government of Italy, Ministry of Education. [MIUR]. (2017). Premio formazione 2017 per l'innovazione della scuola. https://www.miur.gov.it/web/guest/piano-per-la-formazione-dei-docenti.

Government of Spain, Ministry of Education and Vocational Training. (2020a). El Ministerio de Educación y Formación Profesional y las CCAA crean un grupo de trabajo para abordar el desarrollo del próximo curso2020-21.https://www.educacionyfp.gob.es/prensa/actualidad/2020/05/20200514-sectorial.html.

Government of Spain, Ministry of Education and Vocational Training. (2020b). Isabel Celaá avanza 10 líneas de trabajo para modernizar la educación tras la crisis del Covid-19. https://www.educacionyfp.gob.es/prensa/actualidad/2020/05/20200521-comparecenciacongreso.html.

Government of Turkey, Ministry of National Education. [MoNE]. (2020a). Bakan Selçuk, koronavirüs'e karşı eğitim alanında alınan tedbirleri açıkladı. https://www.meb.gov.tr/bakan-selcuk-koronavirusekarsi-egitimalaninda-alinan-tedbirleri-acikladi/haber/20497/tr.

Government of Turkey, Ministry of National Education. [MoNE]. (2020b). Bakan Selçuk, 23 Mart'ta başlayacak uzaktan eğitime ilişkin detayları anlattı. https://www.meb.gov.tr/bakan-selcuk-23-marttabaslayacak-uzaktanegitime-iliskin-detaylari-anlatti/haber/20554/tr.

Government of Turkey, Ministry of National Education. [MoNE]. (2020c). EBA TV ders yayını, https://www.eba.gov.tr/.

Government of Turkey, Ministry of National Education. [MoNE]. (2020d). Türk Eğitim Tarihinin En Büyük Uzaktan Eğitim Mesleki Gelişim Programını Başlatıyoruz. http://oygm.meb.gov.tr/www/turkegitim-tarihinin-en-buyuk-uzaktan-egitim-mesleki-gelisim-programini-baslatiyoruz/icerik/804.

Hamdan Bin Mohammed Smart University. (2020). Ministry of Education and Hamdan Bin Mohammed Smart University qualifies more than 42,000 teachers in UAE \& the region. https:/www.hbmsu.ac.ae/news/ministry-education-and-hamdan-bin-mohammed-smart-universityqualifies-more-42000-teachers-uae.

Hamdan Bin Mohammed Smart University. (2020). Strategic partnership between HBMSU and UNESCO IITE to launch 'Be an Online Tutor in 24 Hours' course in five global languages. https:/www.hbmsu.ac.ae/news/strategic-partnership-between-hbmsu-and-unesco-iite-launch$\%$ E2\%80\%98be-online-tutor-24-hours $\%$ E2\%80\%99-course.

Kırmızı̈ül, H. G. (2020). CoVid-19 Salgini Ve Beraberinde Getirdiği Eğitim Süreci. Avrasya Sosyal ve Ekonomi Araştırmaları Dergisi, 7(5), 283-289.

Loucks-Horsley, S., Stiles, K. E., Mundry, S., Love, N., \& Hewson, P. W. (2009). Designing professional development for teachers of science and mathematics. Corwin press.

Official Newspaper of the Italian Republic. (2020). Law n.18. Enhancement measures of the National Health Service and economic support for families, workers and businesses connected to the 
Şensin, C., Rubat du Mérac, É. (2020). A good scare is worth more than good advice: Educational regulations in Italy and Turkey after CoVid-19. International Journal of Social Sciences and Education Research, 6(3), 429-442.

epidemiological from emergency COVID-19. https://www.gazzettaufficiale.it/eli/id/2020/03/17/20G00034/sg. March 17, 2020.

Official Newspaper of the Italian Republic. (2015). Law n.107. Reform of the national education and training system and delegation for the reorganization of the current legislative provisions. https:/www.gazzettaufficiale.it/atto/serie_generale/caricaDettaglioAtto/originario?atto.dataPubblicazioneGazzetta=2015-07-15\&atto.codiceRedazionale=15G00122\&elenco30giorni=false. July 13, 2015.

Özer, M. (2020). Türkiye'de COVID-19 Salgını Sürecinde Milli Eğitim Bakanlığı Tarafından Atılan Politika Adımları Educational Policy Actions by the Ministry of National Education in the times of COVID19. Kastamonu Education Journal, 28(3), 1124-1129.

Park, S., Oliver, J. S., Johnson, T. S., Graham, P., \& Oppong, N. K. (2007). Colleagues' roles in the professional development of teachers: Results from a research study of National Board certification. Teaching and teacher education, 23(4), 368-389.

Perron, M. (1991). Vers un continuum de formation des enseignants: elements d'analyse. Recherche \& formation, 10(1), 137-151.

Saiti, A., \& Saitis, C. (2006). In-service training for teachers who work in full-day schools. Evidence from Greece. European Journal of Teacher Education, 29(4), 455-470.

Telli, S. G., \& Altun, D. (2020). Coronavirüs ve çevrimiçi (online) eğitimin önlenemeyen yükselişi. Üniversite Araştırmaları Dergisi, 3(1), 25-34.

The National Institute of Documentation, Innovation and Educational Research [INDIRE]. (2020a). Le reti Avanguardie educative, Piccole Scuole e eTwinning a supporto dell'emergenza sanitaria. http://www.indire.it/la-rete-di-avanguardie-educative-a-supporto-dellemergenza-sanitaria/.

The National Institute of Documentation, Innovation and Educational Research [INDIRE]. (2020b). \#iorestoacasa, arrivano i video tutorial per i docent. http://www.indire.it/2020/03/16/iorestoacasa-arrivano-i-video-tutorial-per-i-docenti/.

UNESCO, UNICEF, the World Food Programme \& the World Bank. (2020). Framework for reopening schools. https:/www.unicef.org/media/68366/file/Framework-for-reopening-schools-2020.pdf.

UNESCO. (2020a). COVID-19 crisis and curriculum: sustaining quality outcomes in the context of remote learning. https://unesdoc.unesco.org/ark:/48223/pf0000373273.

UNESCO. (2020b). Distance learning strategies in response to COVID-19 school closures. https://unesdoc.unesco.org/ark:/48223/pf0000373305.

UNESCO. (2020c). Education ministers share plans for the reopening of schools after COVID-19 closures. https://en.unesco.org/news/education-ministers-share-plans-reopening-schools-after-covid-19-closures.

UNESCO. (2020d). Managing high-stakes assessments and exams during crisis. https://unesdoc.unesco.org/ark:/48223/pf0000373387.

UNESCO. (2020e). School reopening. https://unesdoc.unesco.org/ark:/48223/pf0000373275.

UNESCO. (2020f). Supporting teachers and education personnel during times of crisis. https://unesdoc.unesco.org/ark:/48223/pf0000373338.

Copyright (C) by International Journal of Social Sciences and Education Research ISSN: 2149-5939 